\title{
Occurrence and distribution of tetracycline resistance determinants and their pollution profile in selected aquaculture environments in Sri Lanka
}

\author{
G.Y. Liyanage and Pathmalal M. Manage* \\ Centre for Water Quality and Algae Research, Department of Zoology, Faculty of Applied Sciences, University of Sri Jayewardenepura, Nugegoda.
}

\begin{abstract}
Tetracycline (TET) has been extensively used in aquaculture for chemotherapy against various fish diseases. The contamination levels in 16 aquaculture farms in Sri Lanka were analysed using high performance liquid chromatography (HPLC). The presence of antibiotic-resistant bacteria was identified using the 16SrRNA gene sequencing and the corresponding antibiotic resistant genes (ARGs) were screened at each location using the PCR method. The concentration of TET in the aquaculture farm samples ranged between $0.001 \pm 0.001-0.112 \pm 0.017$ ppm. Bacillus and Staphylococcus were recorded as the most dominant resistant bacterial genera against TET. Acinetobacter sp., Achromabacter sp., Staphylococcus sp., Micrococcus sp. were also identified as resistant bacteria. In the present study, tet $(\mathrm{M})$ and tet $(\mathrm{A})$ were the abundant resistance genes (11/16 isolates), followed by tet (S) $(5 / 16)$ and tet $(\mathrm{B})(4 / 16)$. It was found that tet $(\mathrm{M})$ is one of the most widely distributed tetracycline resistance determinants in the aquaculture environment in Sri Lanka.
\end{abstract}

Keywords: Antibiotic resistant genes (ARGs), aquaculture, tetracycline (TET).

\section{INTRODUCTION}

In recent years, there has been an increasing interest in the study of the occurrence and distribution of veterinary antibiotics in the environment, due to their potential adverse effects on the ecosystem and human health (Moges et al., 2014). Among the management of drugs approved for agriculture, antibiotics were widely administered for animal health, especially in aquaculture applications (Allen et al., 2010).

At present, aquaculture production is increasing worldwide as a source for human consumption. It is known that antibiotics are used extensively in aquaculture to treat infectious diseases caused by a variety of bacterial pathogens in aquatic life and as a sub-therapeutic dose to improve production (Pruden et al., 2013; Liyanage \& Manage, 2016b). Antibiotics can be metabolised after administration; however, up to $80 \%$ of the antibiotics administrated are excreted through urine or faeces without complete decomposition (Muziasari et al., 2014). Therefore, it is possible that antibiotics can find their way into the aquatic environment from a variety of sources such as the excretion of animals and discharge from sewage waste. Thus, the prophylactic and therapeutic use of antibiotics result in the occurrence of antibiotic resistant bacteria (ARB) and antibiotic resistance genes (ARGs) in the aquaculture environment (Ritter et al., 2008; Manage \& Liyanage, 2019).

ARGs in the aquaculture environment can be transferred horizontally among microbes and ultimately be transferred to fish as pathogens (Shah et al., 2012). In many Asian countries including Sri Lanka, fish is the major diet of the local people ( $82 \%$ ) because of the consumption habit, health and its nutritional benefits (MFARD, 2016). Therefore, humans have an exposure

*Corresponding author (pathmalal@sjp.ac.lk; (iD http://orcid.org/0000-0002-2014-2060) 
risk to $\mathrm{ARB}$ and $\mathrm{ARGs}$ via ingestion of contaminated aquaculture food and water use. Tetracycline (TET) has been extensively used in aquaculture for chemotherapy against fish diseases such as fin rot and skin ulcers (Mortazavi, 2014), and TET resistant (TETr) bacteria were reported in fish pathogens and environmental bacteria (Ajayi et al., 2013). Aeromonas, Proteus (Vincent et al., 2015) and Pseudomonas (Nikokar et al., 2013) have been reported to carry the resistance genes to TET.

Resistance to TET occurs via two primary mechanisms; one is the energy dependent efflux of TET and the other is production of ribosomal protection proteins (RPPs) (Kim et al., 2004; Zhu et al., 2013).

To regulate antibiotic usage, some monitoring programmes for antimicrobial resistance have been established in Europe, North America and Latin America (Harbarth et al., 2015). However, little information about the status of antibiotic contamination and ARGs is available in Sri Lanka. The annual aquaculture production in Sri Lanka has increased from 44,300 Mt to $334,890 \mathrm{Mt}$ from 1999 to 2014 (NAQDA, 2015).
Therefore, monitoring studies of antibiotics, ARB and ARGs is necessary to develop a safe aquaculture industry in Sri Lanka. Contamination of antibiotics, ARB and ARGs in Vietnam, Thailand (Suzuki \& Hoa, 2012) and South Africa (Suzuki et al., 2015) have recently been reported. As for aquaculture environments in Sri Lanka, frequent use of TET is likely in fish farms.

Thus, the present study aims to determine the status of antibiotic contamination, ARB and ARGs in 16 aquaculture farms (freshwater fish farms, brackish water and shrimp farms) in Sri Lanka. The selected genes in the present study include both efflux pump genes (tet A, tet $\mathrm{B}$ ) and RPP genes (tet $\mathrm{M}$, tet $\mathrm{S}$ ), which are widely detected among the TET resistance genes.

\section{METHODOLOGY}

\section{Chemicals and standards}

Tetracycline, HPLC grade chemicals and bacteriological grade chemicals were purchased from Sigma-Aldrich.

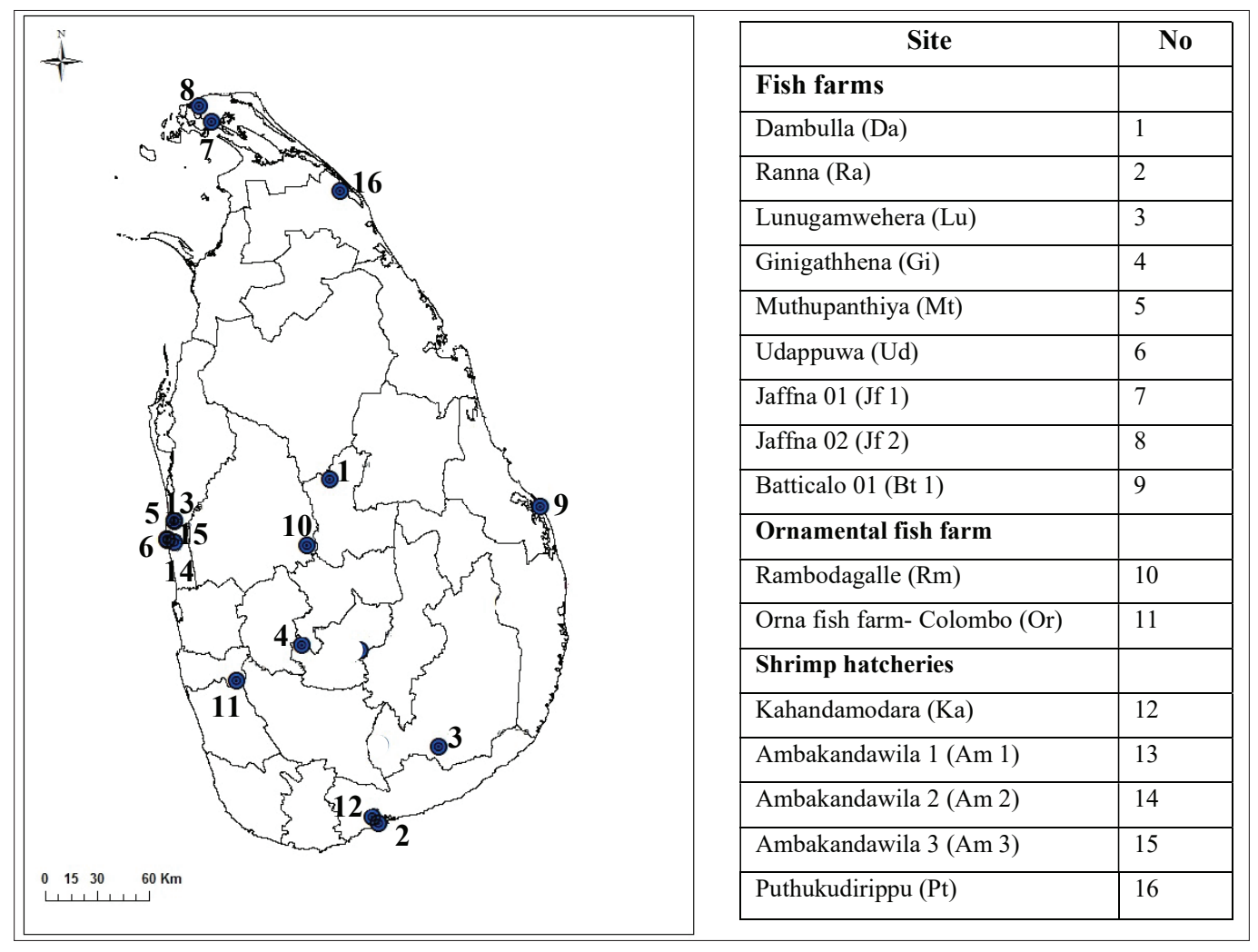

Figure 1: Location map of the sampling sites in the study 


\section{Sampling sites and sample collection}

Triplicate effluent water samples were collected from 16 aquaculture farms: including 9 freshwater food fish farms (Dambulla, Ranna, Lunugamwehera, Ginigathhena, Muthupanthiya, Udappuwa, Jaffna 01, Jaffna 02, Batticaloa 01), 2 ornamental freshwater fish farms (Rambodagalle, Orna-fish farm) and 5 brackish water shrimp farms (Kahandamodara, Ambakandawila 1, Ambakandawila 2, Ambankandawila 3, Puthukudirippu) (Figure 1). Water from Horton Plains were collected as samples from a pristine environment. Water samples were filtered through $150 \mu \mathrm{m}$ plankton nets to remove debris and collected into sterile amber coloured glass bottles. The samples were stored in the dark in an ice box during transportation and then stored at $4{ }^{\circ} \mathrm{C}$ until analysis.

\section{Total viable counts (TVC) of bacteria in environment samples}

The total viable counts were measured using the standard pour plate method with Lauryl-Bertani (LB) medium; Tryptone, $9.1 \mathrm{~g}$; Sodium chloride, $4.6 \mathrm{~g}$; Yeast extract, $4.6 \mathrm{~g}$; agar, $13.1 \mathrm{~g}$; per liter) (Manage et al., 2009). The colony numbers $(\mathrm{CFU} / \mathrm{mL})$ were counted after incubation at $28{ }^{\circ} \mathrm{C}$ for $3-5$ days. For counting of TETr bacteria, TET at a final concentration of $60 \mu \mathrm{g} / \mathrm{mL}$ were added to each medium (Kim et al., 2012; Liyanage \& Manage, 2015; 2018). Bacteria growing on TET treated media were defined as TETr bacteria and enumeration was done after $3 \mathrm{~d}$ of incubation in the dark.

\section{Enrichment and isolation of antibiotic resistant isolates}

From each sampling site, $50 \mathrm{~mL}$ of water was enriched by inoculating TET at final concentration of $60 \mu \mathrm{g} / \mathrm{mL}$ in $100 \mathrm{~mL}$ Erlenmeyer flasks. The final volume was topped up to $100 \mathrm{~mL}$ with sterile water and the flasks were incubated at $28^{\circ} \mathrm{C} \pm 1^{0}$ in $100 \mathrm{rpm}$ for $14 \mathrm{~d}$ in the shaking incubator.

After $14 \mathrm{~d}$ of enrichment, $1 \mathrm{~mL}$ sample aliquots were taken from the flask for isolation and enumeration of bacteria following the modified pour plate method (Manage et al., 2010). LB medium which contained $60 \mu \mathrm{g} / \mathrm{mL}$ of TET was used to isolate TET resistant bacteria (Kim et al., 2012; Liyanage \& Manage, 2014).

After $3 \mathrm{~d}$ of incubation at $28{ }^{\circ} \mathrm{C}$, bacterial colonies with different morphological characters were picked and re-suspended in liquid LB medium. Subsequently, pure bacterial cultures were sub cultured and stored in agar slants at $-20{ }^{\circ} \mathrm{C}$ in LB-glycerol media for further analysis and identification.

\section{Antibiotic susceptibility test}

The LB broth cultures were prepared, and a loop of isolated bacterial strains was inoculated and incubated in shaking incubator in $28{ }^{\circ} \mathrm{C}$ at $100 \mathrm{rpm}$ overnight. The cell density of the bacterial suspension was equalised using McFarland No 0.5 (Liyanage \& Manage, 2014; Jorgensen \& Turnidge, 2015). The minimum inhibition concentration (MIC) was determined by agar dilution method according to Clinical and Laboratory Standards Institute (CLSI) guidelines (CLSI, 2015).

\section{Extraction of environmental DNA from water samples}

For DNA extraction, $250 \mathrm{~mL}$ water sample was collected and filtered through a $47 \mathrm{~mm}$ diameter polycarbonate filter ( $0.22 \mu \mathrm{m}$ pore size, Millipore). Each filter paper was soaked in $10 \mathrm{~mL}$ of $70 \%$ methanol and stored at $-20{ }^{\circ} \mathrm{C}$ until use. Extraction of DNA from the filter papers was carried out following the modified version of Kim et al., (2012). Purified DNA was subjected to PCR analysis.

\section{DNA extraction from isolated bacterial culture}

Isolated bacteria were cultured in $5 \mathrm{~mL}$ of LB liquid medium at $28{ }^{\circ} \mathrm{C}, 100 \mathrm{rpm}$ for $24 \mathrm{~h}$. Cells were harvested by centrifugation at $12,000 \mathrm{rpm}$ for $2 \mathrm{~min}$, and the genomic DNA was extracted following the method described by Kim et al., (2004). Purified DNA was resuspended in $30 \mu \mathrm{L}$ of TE buffer and stored at $-20{ }^{\circ} \mathrm{C}$ until PCR analysis.

\section{Detection of ARGs by PCR}

PCR was performed to detect antibiotic resistant genes and the PCR mixture contained $0.5 \mu \mathrm{L}$ of each primer $(10 \mu \mathrm{m}), 5 \mu \mathrm{L}$ Go taq reaction buffer, $0.5 \mu \mathrm{LdNTPs}$, $2.0 \mu \mathrm{L}$ of $25 \mathrm{mM} \mathrm{MgCl}_{2}$ and $0.1 \mu \mathrm{L}$ of Go taq DNA polymerase, adjusted to a total volume of $25 \mu \mathrm{L}$. Purified DNA $(5 \mu \mathrm{L})$ was used as the PCR template. The optimised conditions used for the primers are shown in Table 1. PCR amplification was conducted in a BIOLAB PCR system (BYQ6078E-757, China) thermal cycler and utilised 35 cycles [denaturation at $95^{\circ} \mathrm{C}$ for $30 \mathrm{~s}$, annealing for $30 \mathrm{~s}$, and extension at $72{ }^{\circ} \mathrm{C}$ for $1 \mathrm{~min}$ ]. A final extension was performed at $72{ }^{\circ} \mathrm{C}$ for $5 \mathrm{~min}$. The amplified products were analysed by electrophoresis on a $1.5 \%$ agarose gel and stained with ethidium bromide. 
Table 1: Optimised conditions for tet primers (Call et al., 2003)

\begin{tabular}{llcc}
\hline Primer pair & Sequence & PCR annealing temp $\left({ }^{\circ} \mathrm{C}\right)$ & Amplicon size (bp) \\
\hline tet $A$-FP & 5'-TTGGCATTCTGCATTCACTC-3' & & 494 \\
tet $A$-RP & 5'-GTATAGCTTGCCGGAAGTCG-3' $^{\prime}$ & 60 & \\
tet $M$ - FP & 5'-ACACGCCAGGACATATGGAT-3' & & 536 \\
tet $M$ - RP & 5'-ATTTCCGCAAAGTTCAGACG-3' & 55 & \\
tet $B$ - FP & 5'-CAGTGCTGTTGTTGTCATTAA-3' & & \\
tet $B$ - RP & 5'-GCTTGGAATACTGAGTGTAA-3' & 60 & \\
tet $S$ - FP & 5'-CGCTACATTTGCGAGACTCA-3' & & 555 \\
tet $S$ - RP & 5'-GAATGCCACTACCCAAAGGA-3' & 46 & \\
\hline
\end{tabular}

\section{Identification of tetracycline resistant bacteria}

A total volume of $200 \mu \mathrm{L}$ of gDNA product was sent to Macrogen, Korea for sequencing. For identification of bacteria, DNA sequences were analysed by the basic local alignment search tool given at the National Center for Biotechnology Information (NCBI) website (http:// www.ncbi.nlm.nih.gov/).

\section{Quantification of tetracycline (TET)}

\section{Extraction of TET from environmental samples using SPE}

One litre of the effluent water sample was adjusted to pH 3 and filtered through $0.22 \mu \mathrm{m}$ nuclearpore filter. Filtered samples were spiked with the standard antibiotic concentration of $10 \mu \mathrm{g} / \mathrm{mL}$ and loaded onto a Sep-Pak Plus C18 cartridge after conditioning with $100 \%$ methanol by followed $5 \mathrm{~mL}$ deionised water (Baquero et al., 2008; Liyanage \& Manage, 2014). Pre-prepared samples were then passed through the cartridges at a flow rate of approximately $1-2 \mathrm{~mL} / \mathrm{min}$ and then rinsed with $5 \mathrm{~mL}$ of deionised water. The analytes were eluted with $3 \mathrm{~mL}$ of $100 \%$ methanol (Liyanage \& Manage, 2014).

\section{HPLC quantification}

TET was quantified using Agilent 1200 series HPLC equipped with a diode array and fluorescence detector (Fernandez-Torres et al., 2010; Liyanage \& Manage, 2014). The injected volume was $20 \mu \mathrm{L}$ and chromatography was performed at $30{ }^{\circ} \mathrm{C}$. The mobile phase consisted of a mixture of $0.1 \%$ glacial acetic acid in water (Component A): $0.1 \%$ glacial acetic acid in acetonitrile (Component B) 99:1 (v/v) was pumped in the beginning at a flow rate of $0.7 \mathrm{~mL} / \mathrm{min}$ for TET. Then followed linear elution gradient from $99 \%$ to $70 \%$ in $25 \mathrm{~min}$ for TET at $230 \mathrm{~nm}$ (Liyanage \& Manage, 2014). Retention time was $10.56 \mathrm{~min}$ for TET. The antibiotic concentrations of the environmental samples were determined by using a calibration curve prepared for TET using external standards from 0.05 to $100 \mu \mathrm{g} / \mathrm{mL}$.

\section{Calibration curves}

The concentration of TET was determined using the following equation, which was derived from the calibration plot for TET.

$\mathrm{C}_{\mathrm{TET}}=\left(\mathrm{A}_{\mathrm{TET}}-7.345\right) / 0.149$

where,

$\mathrm{A}_{\mathrm{TET}}=$ peak area of TET

$\mathrm{C}_{\mathrm{TET}}=$ concentration of TET

The concentration of TET in the environmental sample was obtained by subtracting the corresponding value obtained for a $10 \mu \mathrm{g} / \mathrm{mL}$ aqueous sample of the standard antibiotic treated in the same way as the spiked environmental sample from $\mathrm{C}_{\mathrm{TET}}$.

\section{Recovery test}

The recovery test was carried out for TET as follows. A sample of sterilised distilled water (1 L) was spiked with TET to a final concentration of $100 \mu \mathrm{g} / \mathrm{mL}$. The prepared sample was subjected to solid phase extraction (SPE) by using Sep-Pak Plus C18 cartridge and analysed as described above. A recovery of $87 \%$ was obtained. 


\section{Statistical analysis}

Principal component analysis (PCA) was done for antibiotic concentration in environmental samples and biological parameters of collected water samples in order to see the cluster of sampling locations depending on the presence of antibiotic resistant bacterial strains.

The phylogeny was constructed by neighbour-joining method based on Mega 6/ Cluster W from alignment of antibiotic resistant genes.

All statistical analyses were performed using Minitab 17 software.

\section{RESULTS AND DISCUSSION}

The present study simultaneously investigated the concentrations of TET, TRB and occurrence of tet (M), tet $(\mathrm{S})$, tet $(\mathrm{A})$, tet $(\mathrm{B})$ genes in aquaculture effluent water. It is not clear whether the antibiotics and ARGs from fish feeds and fish excrement remain in aquatic environment in Sri Lanka. In other countries, it is known that the selection for the resistant bacteria and ARGs may have occurred in medicated fish feeds (Fedorova et al., 2014) or inside the fish intestines and fish faeces that entered the water (Xiong et al., 2015), or selection through the antibiotics present in water (Xiong et al., 2015).
Table 2: TET concentrations in water samples collected from fish farms and shrimp hatcheries

\begin{tabular}{lc}
\hline Sampling site & TET $(\mu \mathrm{g} / \mathrm{mL})^{*}$ \\
\hline Fish farms & N.D \\
Dambulla (Da) & $0.002 \pm 0.001$ \\
Ranna (Ra) & $0.001 \pm 0.001$ \\
Lunugamwehera (Lu) & $0.001 \pm 0.001$ \\
Ginigathhena (Gi) & N.D \\
Muthupanthiya (Mt) & N.D \\
Udappuwa (Ud) & $0.076 \pm 0.022$ \\
Jaffna 01 (Jf 1) & $0.008 \pm 0.002$ \\
Jaffna 02 (Jf 2) & $0.005 \pm 0.001$ \\
Batticaloa 01 (Bt 1) & \\
Ornamental fish farm & $0.002 \pm 0.001$ \\
Rambodagalle (Rm) & $0.001 \pm 0.001$ \\
Orna fish farm- Colombo (Or) & \\
Shrimp hatcheries & $0.012 \pm 0.009$ \\
Kahandamodara (Ka) & $0.112 \pm 0.017$ \\
Ambakandawila 1 (Am 1) & $0.092 \pm 0.001$ \\
Ambakandawila 2 (Am 2) & $0.076 \pm 0.022$ \\
Ambakandawila 3 (Am 3) & $0.023 \pm 0.008$ \\
Puthukudirippu (Pt) &
\end{tabular}

Pristine environment

Horton Plains

0.000

N.D: Not detected

*Average \pm standard deviation $(\mathrm{n}=3)$

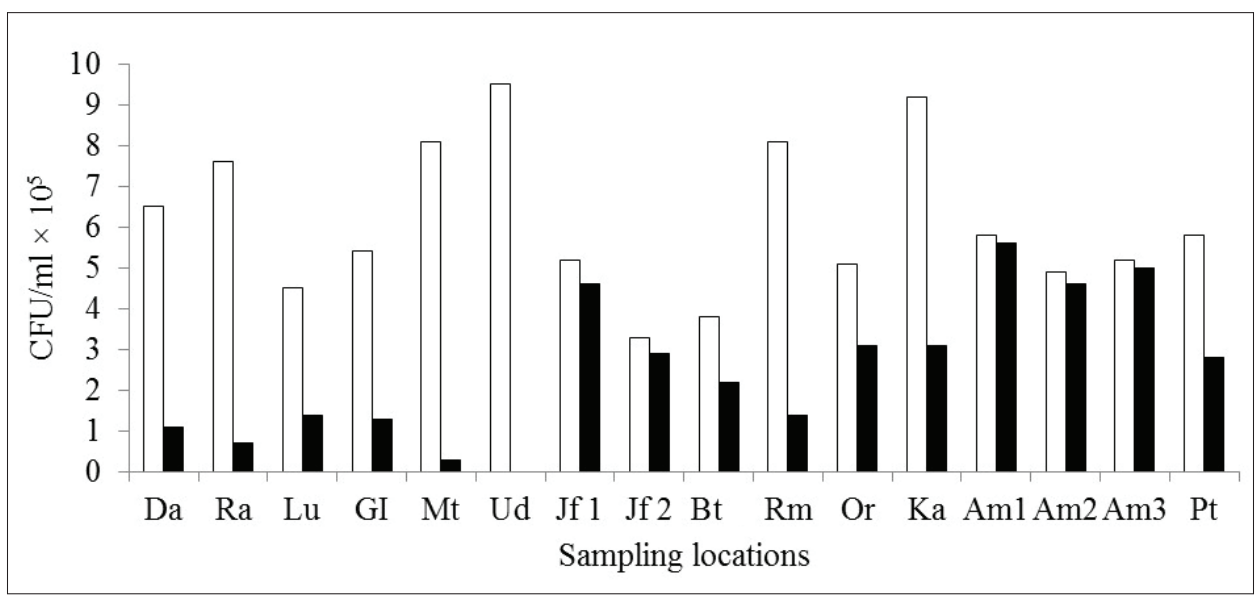

Figure 2: Total viable counts (TVC) ( $\square$ ) and TET resistant bacteria (घ) at each sampling site [fish farms: Da; Dambulla, Ra; Ranna, Lu; Lunugamwehera, Gi; Ginigathhena, Mt; Muthupanthiya, Ud; Udappuwa, Jf 1; Jaffna 01, Jf 2; Jaffna 02, Bt1; Batticaloa 01, Ornamental fish farms: Rm; Rambodagalle, Or; Orna-fish farm, Shrimp hatcheries: Ka; Kahandamodara, Am1; Ambakandawila 1, Am 2; Ambakandawila 2, Am 3; Ambakandawila 3, Pt; Puthukudiirippu] 


\section{Occurrence of TET in water samples}

The concentrations of TET in water samples are presented in Table 2. TET was detected at all sampling locations except Dambulla, Muthupanthiya and Udappuwa.

The concentrations of TET ranged from $0.001 \pm$ $0.001 \mu \mathrm{g} / \mathrm{mL}$ to $0.112 \pm 0.017 \mu \mathrm{g} / \mathrm{mL}$ where the highest concentration was recorded at Ambakandawila 1 and the lowest was at Ginigathhena, Lunugamwehera and Orna fish farm. In Muthupanthiya and Udappuwa aquaculture sites TET was not detected, because aquaculture practices were not being conducted at these sites during the sampling period. High TET concentrations were detected in shrimp hatcheries $(0.012 \pm 0.009 \mu \mathrm{g} / \mathrm{mL}-$ $0.112 \pm 0.017 \mu \mathrm{g} / \mathrm{mL})$ compared with ornamental $(0.001$ $\pm 0.001 \mu \mathrm{g} / \mathrm{mL}-0.002 \pm 0.001 \mu \mathrm{g} / \mathrm{mL})$ and food fish farms $(0.001 \pm 0.001 \mu \mathrm{g} / \mathrm{mL}-0.076 \pm 0.022 \mu \mathrm{g} / \mathrm{mL})$, respectively.

In the present study, TET concentration ranged from 0.001 to $0.112 \mu \mathrm{g} / \mathrm{mL}$. The $\mathrm{WHO}$ recommended concentration is less than $0.001 \mu \mathrm{g} / \mathrm{mL}$ of antibiotic residues in the aquatic environment and less than $0.1 \mu \mathrm{g} / \mathrm{mL}$ in soil (Connor \& Aga, 2007). Thus, the results of the present study showed that antibiotics detected in effluent water exceeded the recommended concentrations given by the WHO (WHO, 2015).

The high frequency of detection and concentration of TET are likely due to the large amount of TET used for feed additives and to control infectious diseases in aquaculture sites (Shah et al., 2014). The antibiotic concentration levels found in the present study are higher than those reported in some developed countries such as Victoria Harbor, China, Japan, Vietnam (Gao et al., 2012) and South Africa (Chenia \& Vietze, 2012).

Water samples collected from Horton Plains, which was declared a World Heritage Site (WHS) by UNESCO (UNESCO, 2010) and situated $2100 \mathrm{~m}$ above sea level, were considered as reference samples from a 'pristine' environment. TET and ARGs were not detected in Horton Plains.

\section{Total viable bacterial counts (TVC)}

As shown in Figure 2, total viable counts (TVC) of cultivable bacteria ranged between $3.3 \times 10^{5}-9.5 \times 10^{5}$ $\mathrm{CFU} / \mathrm{mL}$ in the sampling sites. The highest TVC of cultivable bacteria was recorded in Udappuwa $(9.5 \times$ $10^{5} \mathrm{CFU} / \mathrm{mL}$ ) whereas the lowest TVC was detected in Jaffna farm $2\left(3.3 \times 10^{5} \mathrm{CFU} / \mathrm{mL}\right)$.

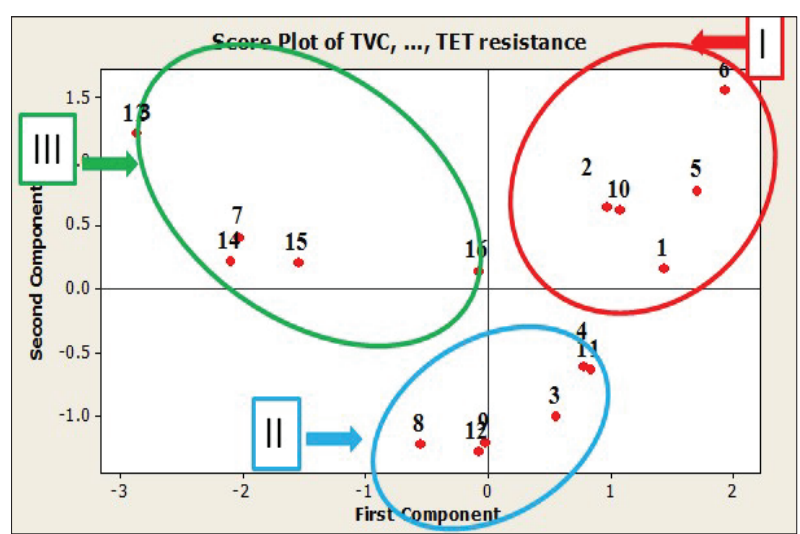

Figure 3: PCA analysis for total viable count, TET concentration CFU of TETr bacteria

The resistance percentages for TETr (defined as the number of bacteria that grew on antibiotic plates divided by the total number of bacteria that grew on plates containing no antibiotics) were calculated for effluent water samples from each sampling site.

The TETr bacterial percentage in fish farms varied between 2.1 to $72.91 \%$; in ornamental fish farms between 7.84 to $12.16 \%$ and in shrimp hatcheries between $13.41 \%$ to $78.18 \%$, respectively. TETr bacteria were not detected in Dambulla and Muthupanthiya aquaculture sites. This may be due to the lack of prior exposure to TET at these sampling sites (Table 2).

The results obtained from PCA are shown in Figure 3. The clusters (I, II, III) correspond to TVC, CFU of TETr bacteria and TET concentration. TET concentrations and number of resistant bacteria were recorded to be high in cluster III compared to clusters I and II. In cluster I and II, detected antibiotic concentrations were very low, or not in the detectable level. Thus, antibiotic concentration and the number of resistant bacteria exhibited a strong relationship.

Gao et al., (2012) reported that the rate of occurrence of TETr bacteria was high in aquaculture farms in Northern China compared to other environments. In previous studies, the recorded percentage of tetracycline resistant bacteria in fish farms in Malaysia varied from 2.7 to $60.7 \%$ (Shariff et al., 2000), whereas it varied between 4.7 to $64.8 \%$ in shrimp hatcheries in Singapore (Shariff et al., 2000) and the percentage of occurrence of TETr bacteria against $60 \mu \mathrm{g} / \mathrm{mL}$ of TET was from 0.79 to $14.7 \%$ in ornamental fish farms in Malaysia (Shariff et al., 2000). Compared to these, the results of the 
present study were more or less similar to the recorded concentrations for ornamental and shrimp hatcheries.

Contrary to the present study, a higher incidence of bacterial resistance to TET at aquaculture farms was found in Australia, Denmark and the Netherlands by comparing resistance percentages in shrimp hatcheries (Akinbowale et al., 2006). The results of the present study showed high percentage of occurrence (2.1 $78.1 \%$ ) of TETr bacteria compared to the other studies (Shariff et al., 2000; Akinbowale et al., 2006). The findings suggest that TETr bacteria is linked to various drug resistance mechanisms, but a specific trend of pattern would be present due to regional differences (Akinbowale et al., 2006). Additionally, the distribution of antibiotics also depends on the physical and chemical stability of antibiotics (Martinez, 2017).

\section{Identification of antibiotic resistant bacteria}

Forty strains of bacteria were randomly isolated from aquaculture effluent water. $16 \mathrm{~S}$ rRNA analysis was carried out to identify the isolated TETr bacteria. Species composition of TET resistant bacteria, the resistant genes detected and their MIC values are summarised in Table 3.

Table 3: $\quad$ MIC of tetracycline and detection of tet (M), tet (S), tet (A) and tet (B) genes in tetracycline resistant bacteria isolated from aquaculture farms

\begin{tabular}{|c|c|c|c|c|c|c|}
\hline Isolate & Group or species & $\operatorname{MIC}(\mu \mathrm{g} / \mathrm{mL})$ & tet $(\mathrm{M})$ & tet $(\mathrm{S})$ & $\operatorname{tet}(\mathrm{A})$ & tet $(\mathrm{B})$ \\
\hline HF586507 & Achromobacter sp. & 760 & + & - & - & - \\
\hline DQ174269 & Achromobacter xylosoxidans & 550 & + & - & + & + \\
\hline NR042387 & Acinetobacter calcoacetius & 640 & - & + & + & - \\
\hline KL234156 & Aeromonas hydrophila & 680 & + & + & + & - \\
\hline FJ982654 & Bacillus cereus & 410 & + & + & - & - \\
\hline KN514297 & Bacillus thurengiensis & 420 & + & + & + & - \\
\hline D1186353 & Bacillus sp. & 360 & + & - & - & - \\
\hline HV492635 & Bacillus sp. & 780 & - & - & + & - \\
\hline AS238910 & Bacillus pumilus & 670 & - & - & + & - \\
\hline HF947328 & Staphylococcus sp. & 580 & + & + & + & + \\
\hline KU691844 & Flexibacter sp. & 540 & + & - & + & + \\
\hline AS678425 & Bacillus anthracis & 450 & + & - & + & - \\
\hline PR617299 & Pseudomonas aeruginosa & 840 & + & - & + & - \\
\hline LS345678 & Micrococcus luteus & 430 & - & - & - & + \\
\hline KS675433 & Staphylococcus epidermis & 620 & + & - & - & - \\
\hline KS678987 & Staphylococcus haemolyticus & 320 & + & - & - & - \\
\hline
\end{tabular}

The genera Achromobacter, Micrococcus, Pseudomonas and Acinetobacter are recognised as proteobacteria, while Bacillus and Staphylococcus belong to the firmicutes group. Bacillus was found to be the most dominant resistant genus in the present study.

The isolated strains except Bacillus thuringiensis have been recorded as pathogenic bacteria that cause different diseases such as fin rot, mouth rot, skin ulcers and abdominal swelling in fish and shrimp (Vincent et al., 2015).

MIC values of TETr bacteria varied from $320 \mu \mathrm{g} / \mathrm{mL}$ to $840 \mu \mathrm{g} / \mathrm{mL}$. The highest MIC was recorded for Pseudomonas aeruginosa and the lowest was for Staphylococcus haemolyticus.

The tet $(\mathrm{M})$ and tet $(\mathrm{S})$ are well studied ribosomal protection protein genes, which are known to be distributed widely in the aquatic environment, whereas tet (A) and tet (B) are considered as genes that efflux tetracycline from the cell (Vincent et al., 2015).

In the present study, 12 strains out of 16 isolates were positive for tet $(\mathrm{M})$ and 10 out of 16 strains were positive for tet (A), suggesting that these genes were harboured in cultural bacteria in aquaculture farms effluent water. In contrast, tet $(\mathrm{S})(5 / 16)$ and tet $(\mathrm{B})(4 / 16)$ were detected only in a few TETr isolates. 
Either tet (M) or tet (A) gene was detected in most of the resistant bacteria and the detection frequency was $68.75 \%$ for both genes whereas a detection frequency for tet (S) and tet (B) were recorded as $31.25 \%$ and $25 \%$, respectively.

Bacillus sp., Achromabacter sp. and Staphylococcus $\mathrm{sp}$. were found to be the most dominant resistant strain in TETr bacteria in the present study. These results are different from a study conducted in Vietnamese shrimp and fish ponds where Acinetobacter was the commonest tetracycline resistant bacterium (Hoa et al., 2011). Another study in Vietnamese shrimp ponds found that Vibrio sp. was a common tetracycline-resistant bacterium, followed by Bacillus (Bien et al., 2015). These results may reflect regional differences in species composition of the bacteria population. Bonnin et al., (2013) also pointed out that the presence of Bacillus strains producing antimicrobial compounds may contribute to the high incidence of bacterial resistance to the antibiotics studied.

In the present study, some species of Pseudomonas, Staphylococcus, Achromobacter, Flexibacter, Aeromonas and Micrococcus are considered as pathogenic microorganisms which cause fish diseases such as fin rot and ulcers (Ritter et al., 2008). Therefore, bacteria resistant to antibiotics in the intestinal tract are excreted into the environment and then ARG transfer may occur between indigenous bacteria and intestinal bacteria, possibly spreading ARGs to human pathogens, thereby posing a risk to human health. Thus, the results of the study suggest that ARB isolated from fish ponds which belong to diverse taxonomic bacterial groups may be an important reservoir of a diverse group of tetracycline resistant genes conferring resistance by different mechanisms.

tet $(\mathrm{M})$ gene has been detected at high percentages in bacteria, isolated from aquaculture sites in Korea and Japan (Kim et al., 2004). Similarly, this study also detected tet (M) in many isolated resistant bacteria strains (Table 3).

\section{PCR detection of ARGs in water samples}

tet $(\mathrm{M})$ gene was detected in 14 sampling sites out of 16 , while tet (A), tet (B) and tet (S) were detected in 9, 4 , and 6 sampling sites, respectively. From the target ARGs, tet (A), tet $(\mathrm{M})$ and tet $(\mathrm{S})$ genes were found at three sampling sites, namely, Rambodagalle, Jaffna farm 1 and Batticaloa 1 whereas tet (A) and tet (M) genes were recorded at seven sampling sites of Dambulla, Rambodagalle, Udappuwa, Jaffna farm 1, Batticaloa, Ambakandawila 3 and Puthukuduirippu. Interestingly, TETr bacteria were not detected in Udappuwa sampling site, although tet (A) and tet (M) genes were detected (Figure 5).

Accordingly, the present study recorded tet (M) at many sampling sites whereas tet (S), tet (A) and tet (B) were found in only limited sampling sites (Figure 5). Further, a high detection frequency of tet (M) was recorded in this study and similar results were reported in Vietnamese shrimp and fish ponds as well (Hoa et al., 2011; Novais et al., 2012).

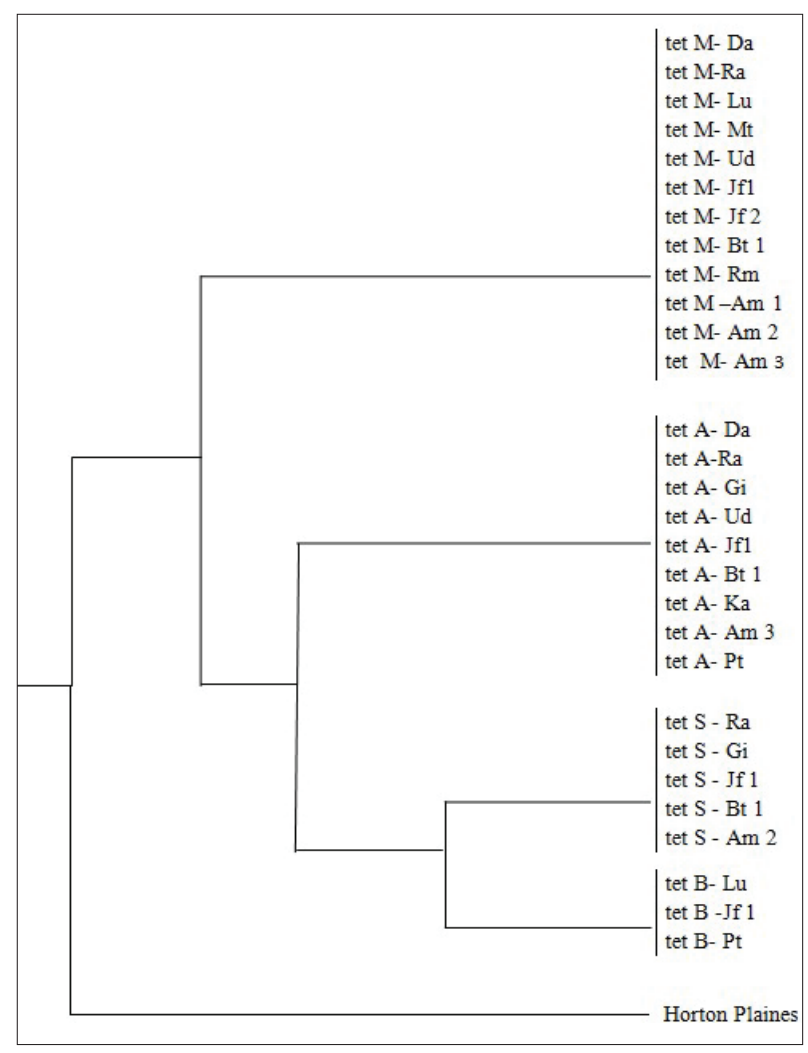

Figure 5: Phylogenetic tree of tet $(M)$, tet $(A)$, tet $(S)$ and tet $(B)$ from environmental DNA in water samples [fish farms: Da; Dambulla, Ra; Ranna, Lu; Lunugamwehera, Gi; Ginigathhena, Mt; Muthupanthiya, Ud; Udappuwa, Jf 1; Jaffna 01, Jf 2; Jaffna 02, Bt1; Batticaloa 01, Ornamental fish farms: Rm; Rambodagalle, Or; Orna-fish farm, Shrimp hatcheries: Ka; Kahandamodara, Am1; Ambakandawila 1, Am 2; Ambakandawila 2, Am 3; Ambakandawila 3, Pt; Puthukudiirippu] 
Moreover, the presence of antibiotics in sub-inhibitory concentration may induce the horizontal gene transfer system in bacterial communities (Suzuki et al., 2008; Ryu et al., 2012; Manage, 2018), which further increases the prevalence of ARGs.

The results of the present study indicates that fish farms and shrimp hatcheries are reservoirs of ARGs and the presence of potential resistant and pathogen-associated taxonomic groups in fish farms have implications for human health. To the best of our knowledge, this is the first study on detecting the status of antibiotic contamination, ARGs, and composition of the antibiotic resistant bacterial community in selected aquaculture environments in Sri Lanka. The results highlight the negative impacts of overuse of antibiotics in aquaculture and the potential risk to human health.

\section{CONCLUSION}

The study demonstrates that aquaculture farms are a reservoir of TET, ARB and ARGs. The TETr bacteria, especially the possible opportunistic pathogens isolated from aquaculture environments and the presence of TETr genes, implies an urgent need for implementing a monitoring system for antibiotic usage in aquaculture, as ARGs and isolated ARB in farm water may lead to disease outbreaks which would eventually lead to production losses at fish and shrimp farms. Further, the ARB and ARGs might have an impact on human society. Understanding the route and mechanisms of ARG proliferation are steps to mitigate the risks to human health.

\section{Acknowledgement}

The authors wish to thank Prof. S. Suzuki, Center for Marine Environmental Studies, Matsuyama, Ehime University, Japan for constructive suggestions for this study and the University of Sri Jayewardenepura for providing financial support (ASP/06/RE/SCI/2013/20; Centre for water quality and algae research).

\section{REFERENCES}

Ajayi A.O., Olumekun V.O. \& Okoh A.I. (2013). Aquaculture disease control through antibiotics surveillance test. American-Eurasian Journal of Agriculture and Environmental Science 13(9): 1176-1180.

Akinbowale O.L., Peng H. \& Barton M.D. (2006). Antimicrobial resistance in bacteria isolated from aquaculture sources in Australia. Journal of Applied Microbiology 100 (5):
1103-1113.

DOI: https://doi.org/10.1111/j.1365-2672.2006.02812.x

Allen H.K., Donato J., Wang H.H., Cloud-Hansen K.A., Davies J. \& Handelsman J. (2010). Call of the wild: antibiotic resistance genes in natural environments. Nature Reviews Microbiology 8: 251-259.

DOI: https://doi.org/10.1038/nrmicro2312

Baquero F., Martinez J.L. \& Canton R. (2008). Antibiotics and antibiotic resistance in water environments. Current Opinion Biotechnology 19(3): 260-265.

DOI: https://doi.org/10.1016/j.copbio.2008.05.006

Bien T.L.T., Sato-Takabe Y., Ogo M., Usui M. \& Suzuki S. (2015). Persistence of multi-drug resistance plasmids in sterile water under very low concentrations of tetracycline. Microbes and Environments 30(4): 339-343. DOI: https://doi.org/10.1264/jsme2.ME15122

Bonnin R.A., Nordmann P. \& Poirel L. (2013). Screening and deciphering antibiotic resistance in Acinetobacter baumannii: a state of the art. Expert review of Anti-Infective Therapy 11(6): 571-583.

DOI: https://doi.org/10.1586/eri.13.38

Call D.R., Bakko M.K., Krug M.J. \& Roberts M.C. (2003). Identifying antimicrobial resistance genes with DNA microarrays. Antimicrobial Agents and Chemotherapy 47(10): 3290-3295.

DOI: https://doi.org/10.1128/AAC.47.10.3290-3295.2003

Chenia H.Y. \& Vietze C. (2012). Tetracycline resistance determinants of heterotrophic bacteria isolated from a South African tilapia aquaculture system. African Journal of Microbiology Research 6(39): 6761-6768.

DOI: https://doi.org/10.5897/AJMR10.840

Clinical and Laboratory Standards Institute (CLSI) (2015). CLSI Guidelines. Available at http://clsi.org/wp-content/ uploads/sites/14/2013/07/CLSI-2015-Catalog.pdf. Accessed 5 March 2017.

Connor S.O. \& Aga D.S. (2007). Analysis of tetracycline antibiotics in soil; advances in extraction, clean-up, and quantification. TrAC Trends in Analytical Chemistry 26: 456-465.

DOI: https://doi.org/10.1016/j.trac.2007.02.007

Fedorova G., Nebesky V., Randak T. \& Grabic R. (2014). Simultaneous determination of 32 antibiotics in aquaculture products using LC-MS/MS. Chemical Papers 68(1): 2936.

DOI: https://doi.org/10.2478/s11696-013-0428-3

Fernandez-Torres M.O., Consentino M.A., Bello Lopez. \& Larsen J.L. (2010). Simultaneous determination of 11 antibiotics and their main metabolites from four Different groups by reversed-phase high performance liquid chromatography-diode array -fluorescence (HPLC-DADFLD) in human urine sample. Talanta 81: 871-880.

DOI: https://doi.org/10.1016/j.talanta.2010.01.031

Gao P., Mao D., Luo Y., Wang L., Xu B. \& Xu L. (2012). Occurrence of sulfonamide and tetracyclineresistant bacteria and resistance genes in aquaculture environment. Water Research 46(7): 2355-2364. DOI: https://doi.org/10.1016/j.watres.2012.02.004 
Harbarth S., Balkhy HH., Goossens H., Jarlier V., Kluytmans J., Laxminarayan R. \& Pittet D. (2015). Antimicrobial resistance: one world, one fight. Antimicrobial Resistance and Infection Control 49: 23-32.

DOI: https://doi.org/10.1186/s13756-015-0091-2

Hoa P.T.P., Managaki S., Nakada N., Takada H., Shimizu A., Anh D.H., Viet P.H. \& Suzuki S. (2011). Antibiotic contamination and occurrence of antibiotic-resistant bacteria in aquatic environments of northern Vietnam. Science of the Total Environment 409: 2894-2901. DOI: https://doi.org/10.1016/j.scitotenv.2011.04.030

Jorgensen J.H. \& Turnidge J.D. (2015). Susceptibility test methods: dilution and disk diffusion methods. Jorgenson Journal 6: 1253-1273.

DOI: https://doi.org/10.1128/9781555817381.ch71

Kim S.J., Ogo M., Oh M.J. \& Suzuki S. (2012). Occurrence of tetracycline resistant bacteria and tet $(\mathrm{M})$ gene in seawater from Korean coast. Interdisciplinary studies on environmental chemistry-Environmental pollution and ecotoxicology. TERRAPUB, Tokyo, pp. 367-375.

Kim S.R., Nonaka L. \& Suzuki S. (2004). Occurrence of tetracycline resistance genes tet $(\mathrm{M})$ and tet $(\mathrm{S})$ in bacteria from marine aquaculture sites. FEMS Microbiology Letters 237 (1): 147-156.

DOI: https://doi.org/10.1016/j.femsle.2004.06.026

Liyanage G.Y. \& Manage P.M. (2015). Presence of tetracycline and oxytetracycline resistant bacteria and resistant genes in effluent water of zoological garden, Sri Lanka. Proceeding of $12^{\text {th }}$ International Academic Conference on Development in Science and Technology (IACDST-2015), pp. 15-19.

Liyanage G.Y. \& Manage P.M. (2016a). Occurrence, fate and ecological risk of antibiotics in hospital effluent water and sediments in Sri Lanka. International Journal of Agriculture and Environmental Research 4: 909-935.

Liyanage G.Y. \& Manage P.M. (2016b) Occurrence and distribution of tetracycline resistance determinants and their pollution status in the aquaculture environment of Sri lanka. $3^{\text {rd }}$ International Conference on Multidisciplinary Approaches, Proceeding 8.

Liyanage G.Y. \& Manage P.M. (2018). Degradation of ciprofloxacin (CIP) by bacteria isolated from effluent water and identification of degradation pathways. International Journal of Medical, Pharmacy and Drug Research 2(3): 37-47.

DOI: https://doi.org/10.22161/ijmpd.2.3.1

Liyanage Y. \& Manage P.M. (2014). Quantification of oxytetracycline and ampicillin in two waste water discharging points in Colombo, Sri Lanka. Environment and Natural Resources Journal 1: 195-198.

Manage P.M., Edwards C. \& Lawton L. (2010). Bacterial degradation of microcystin. interdisciplinary studies on environmental chemistry-biological responses to contaminants. TERRAPUB: Tokyo: 97-104

Manage P.M., Edwards C., Singh B.K. \& Lawton L.A. (2009). Isolation and identification novel microcystin degrading bacteria. Applied Environmental Microbiology 75(21): 6924-6928.

DOI: https://doi.org/10.1128/AEM.01928-09
Manage P.M. \& Liyanage G.Y. (2019). Antibiotics induced antibacterial resistance. In: Pharmaceuticals and Personal Care Products: Waste Management and Treatment Technology, pp. 429-444, Elsevier.

DOI: https://doi.org/10.1016/B978-0-12-816189-0.00018-4

Manage P.M. (2018). Heavy use of antibiotics in aquaculture: Emerging human and animal health problems-A review. Sri Lanka Journal of Aquatic Science 23 (1):13-28.

DOI: https://doi.org/10.4038/sljas.v23i1.7543

Martínez J.L. (2017). Effect of antibiotics on bacterial populations: a multi-hierarchical selection process. F1000Research 6: 51.

DOI: https://doi.org/10.12688/f1000research.9685.1

Ministry of Fisheries and Aquatic Resources Development (MFARD) (2016). Available at $h t t p: / / w w w$. fisheries.gov.lk/ content.php? cnid=ststc. Accessed on 5 January 2016.

Moges F., Endris M., Belyhun Y. \& Worku W. (2014). Isolation and characterization of multiple drug resistance bacterial pathogens from waste water in hospital and non-hospital environments,North west Ethiopia. BMC Research Notes 7: 215.

DOI: https://doi.org/10.1186/1756-0500-7-215

Mortazavi A.L. (2014). Poppin'the prophylactics: an analysis of antibiotics in aquaculture. The Journal of |Global Health. Available at http://www.ghjournal.org/poppin-theprophylactics-an-analysis-of-antibiotics-in-aquaculture/. Accessed 3 March 2017.

Muziasari W.I., Managaki S., Pärnänen K., Karkman A., Lyra C., Tamminen M., Suzuki S. \& Virta M. (2014). Sulphonamide and trimethoprim resistance genes persist in sediments at Baltic Sea aquaculture farms but are not detected in the surrounding environment. PloS One 9(3): e92702.

DOI: https://doi.org/10.1371/journal.pone.0092702

National Aquaculture Development Authority of Sri Lanka (2015). Available at http://www.naqda.gov.lk/ Accessed 2 December 2016.

National Center for Biotechnology Information (NCBI). Available at http://www.ncbi.nlm.nih.gov/ Accessed 12 January 2017.

Nikokar I., Tishayar A., Flakiyan Z., Alijani K., RehanaBanisaeed S., Hossinpour M., Amir-Alvae S. \& Araghian A. (2013). Antibiotic resistance and frequency of class 1 integrons among Pseudomonas aeruginosa, isolated from burn patients in Guilan, Iran. Iranian Journal of Microbiology 5(1): 36-41.

Novais C., Freitas A.R., Silveira E., Baquero F., Peixe L., Roberts A.P. \& Coque T.M. (2012). Different genetic supports for the tet (S) gene in enterococci. Antimicrobial Agents and Chemotherapy 56(11): 6014-6018. DOI: https://doi.org/10.1128/AAC.00758-12

Pruden A. et al., (13 authors) (2013). Management options for reducing the release of antibiotics and antibiotic resistance genes to the environment. Environmental Health Perspectives 121(8): 878-884. DOI: https://doi.org/10.1289/ehp.1206446

Ritter J.M., Lewis L.D., Mant T.G.K. \& Ferro A. (2008). Clinical Pharmacology and Therapeutics, $5^{\text {th }}$ edition, Hodder Arnold Hachette Livre, UK. 
Ryu S.H., Lee J.H., Park S.H., Song M.O., Park S.H., Jung H.W. \& Lee Y.K. (2012). Antimicrobial resistance profiles among Escherichia coli strains isolated from commercial and cooked foods. International Journal of Food Microbiology 159(3): 263-266.

DOI: https://doi.org/10.1016/j.ijfoodmicro.2012.09.001

Shah S.Q., Cabello F.C., L'Abee-Lund T.M., Tomova A., Godfrey H.P., Buschmann A.H. \& Sørum H. (2014). Antimicrobial resistance and antimicrobial resistance genes in marine bacteria from salmon aquaculture and non-aquaculture sites. Environmental Microbiology 16(5): 1310-1320.

DOI: https://doi.org/10.1111/1462-2920.12421

Shah S.Q.A., Colquhoun D.J., Nikuli H.L. \& Sorum H. (2012). Prevalence of antibiotic resistance genes in the bacterial flora of integrated fish farming environments of Pakistan and Tanzania. Environmental Science and Technology 46: 8672-8679.

DOI: https://doi.org/10.1021/es3018607

Shariff M., Nagaraj G., Chua F.H.C. \& Wang Y.G. (2000). The use of chemicals in aquaculture in Malaysia and Singapore. In: Use of Chemicals in Aquaculture in Asia (eds. J.R. Arthur, C.R. Lavilla Pitogo, R.P. Subasinghe). Iloilo, Philippines, Southeast Asian Fisheries Development Centre, pp. 127-140.

Suzuki S. \& Hoa P.T.P. (2012). Distribution of quinolones, sulfonamides, tetracyclines in aquatic environment and antibiotic resistance in Indochina. Frontiers in Microbiology 3: 67

DOI: https://doi.org/10.3389/fmicb.2012.00067

Suzuki S., Ogo M., Koike T., Takada H. \& Newman B. (2015). Sulfonamide and tetracycline resistance genes in total-and culturable-bacterial assemblages in South African aquatic environments. Frontiers in Microbiology 6: 796-801.

DOI: https://doi.org/10.3389/fmicb.2015.00796

Suzuki S., Takeshi K., Fujiyo S., Bui CachTuyen \& Tough S.T. (2008). High Occurrence rate of tetracycline resistant bacteria and TC resistance gene relates to microbial diversity in sediment of Mekong river mail water way. Microbes Environment 23: 149-152.

DOI: https://doi.org/10.1264/jsme2.23.149

UNESCO. (2010). Available at http://whc.unesco.org/en/ list/1203. Accessed 24 December 2016.

Vincent A.T., Tanaka K.H., Trudel M.V., Frenette M., Derome N. \& Charette S.J. (2015). Draft genome sequences of two Aeromonas salmonicida subsp. salmonicida isolates harboring plasmids conferring antibiotic resistance. FEMS microbiology letters 362 (4): 1-4.

DOI: https://doi.org/10.1093/femsle/fnv002

World Health Organization (2015). Global Action Plan on Antimicrobial Resistance. Available at http://www.who. int/drugresistance/global_action_plan/en/. Accessed 13 February 2017.

Xiong W., Sun Y., Zhang T., Ding X., Li Y., Wang M. \& Zeng Z. (2015). Antibiotics, antibiotic resistance genes, and bacterial community composition in freshwater aquaculture environment in China. Microbial Ecology 70 (2): 425-432. DOI: https://doi.org/10.1007/s00248-015-0583-X

Zhu Y.G., Johnson T.A., Su J.Q., Qiao M., Guo G.X., Stedtfeld R.D. \& Tiedje J.M. (2013). Diverse and abundant antibiotic resistance genes in Chinese swine farms. Proceedings of the National Academy of Sciences USA 110 (9): 3435-3440. DOI: https://doi.org/10.1073/pnas. 1222743110 